\title{
BARRIERS TO A NATIONAL PRIMARY LAW
}

\author{
RICHARD H. HANSEN*
}

\section{INTRODUCTION}

On April 12, 1808, Senator Hillhouse, a Federalist from New York, presented the first constitutional amendment offered in Congress to alter the method of nominating and electing the President. He proposed that senators be elected for staggered threeyear terms. Every year the retiring senators would meet and, after being blindfolded, each would draw a ball from a bóx. The senator drawing the colored ball would be President for the ensuing year. ${ }^{1}$

During the first session of the Eighty-seventh Congress, a multitude of bills to change the procedure for nominating the President were introduced, as they have been in nearly every Congress since I808. Like their predecessors since I9I3, the rg6r bills suggested a national primary. Without strong presidential support a national primary bill in this or any future Congress will not receive a favorable committee report; with such backing a bill might reach the floor of either house, where its defeat is assured. On the basis of past performance this is the pattern in Congress. There are two conditions which insure this result: (I) the ponderous and impracticable nature of the majority of the bills; (2) the enormous expense a national primary would entail for presidential aspirants.

\section{I}

\section{National Primary Bilis Tend to Be Impracticable}

Senator Hillhouse not only introduced the first constitutional amendment to change the nominating procedure, but he set the tone of most of the succeeding proposals. $^{2}$ The impracticable spirit of his bill permeates the cumbersome legislation advanced to create a national primary.

The "run-off" primary bills are a concrete example of the lengthy procedures suggested. ${ }^{3}$ The convention system would be retained in most of these bills, but only for drafting a platform and selecting the five or six top candidates for the nomination. The names of these men would be submitted to the voters at a postconvention primary. The candidates receiving the highest number of votes would be the party's nominee.

* B.S. 1953, LL.B. 1956, University of Nebraska. Member of the Lincoln, Nebraska, and American bar associations.

${ }^{1}$ S. 273, Ioth Cong., Ist Sess. (1808); I Annals of Cong. 357-58 (1852) [1807-1808]. No less a personage than Chief Justice Marshall favored the Hillhouse amendment.

${ }^{2}$ Following 1808 , the idea of selection by lot was suggested intermittently. See Ames, Proposed Amendments to the Constitution, H.R. Doc. No. 353, pt. 2, 54th Cong., 2 d Sess. 98 (1897).

${ }^{3}$ The idea was first advanced by Pulsifer, The Pig and the Primary-A Complaint, $A$ Plan, and $A$ Doubtful Conclusion, The Outlook, Sept. 1, I920, p. 19. An example of current proposed legislation providing for a run-off primary is S.J. Res. I, 87th Cong., Ist Sess. (I96I). 
As a rule, nothing is said in these bills about how the delegates to the convention would be chosen. In a state like Nebraska, where delegates are elected in a primary, three elections would be required to choose a President: one for electing delegates, one for choosing a nominee, and the last for choosing a President. Former President Truman characterizes such a run-off primary as a "monstrosity" because "it takes forever to get your candidate nominated."4

The most valid objection to the run-off primary is the likelihood of a plurality nominee. Should the names of five candidates be submitted to the people the winner could receive only thirty per cent of the vote and seventy per cent of the electorate would be, in effect, disfranchised. ${ }^{5}$

The unrealistic quality of national primary bills has not been confined to the "run-off" legislation. The visionary approach is represented in the late Senator Langer's bill in the Eighty-fourth Congress, ${ }^{6}$ and the one presented by Senator Smathers in the Eighty-seventh Congress. ${ }^{7}$ Langer's proposal would have led to a plurality nominee, and Smathers' long and complicated bill would project all of the vagaries of the electoral college system into the field of nominations.

The extremely idealistic and visionary character of most of these bills has resulted in loss of support from many people who would endorse a simpler and more reasonable approach.

\section{II}

\section{The ExPENSE FACtoR}

The idea of a national primary is criticized most vehemently and logically because of the expense entailed for presidential candidates. Party lines merge into vocal opposition when the expense question is raised. Harry S. Truman and Thomas E. Dewey, partisan antagonists, agree in their denunciation of a national primary because of this factor:

THOMAS E. DEWEY: Any man who has time to run in [fifty] state primaries is unemployed. Moreover, since he is strictly an individual seeking nomination, he would incur obligations to contributors all over the nation and the amounts of money could run into the millions. No candidate should have that kind of personal obligation. ${ }^{8}$

HARRY S. TRUMAN: When you take a national primary and require a man to campaign in [fifty] states it would be one of the most expensive procedures possible for the individual candidate and the man with the money would be in a better position to present his case than the man without money. . . . the old saying is that any man can run for President, but as a practical matter it isn't true, because not every man can afford it.

Interview with Harry S. Truman, July 25, 1953.

Candidate No. I could receive $25 \%$; No. 2 , $17 \%$; No. $3,30 \%$; No. $4,13 \%$; and No. $5, x 5 \%$.

${ }^{\circ}$ S.J. Res. I0, 85 th Cong., Ist Sess. (1955).

${ }^{7}$ S.J. Res. 9, 87th Cong., Ist Sess. (196r).

${ }^{8}$ Letter from Thos. E. Dewey to Richard H. Hansen, Aug. I2, 1959.

${ }^{\circ}$ Letter from Harry S. Truman to the author, Oct. 22, 1953. Compare the comments of the following two gentlemen:

JOSEPH W. MARTIN, JR. (Three-time Chairman of the Republican National Convention and former Speaker of the House): "I would not believe in a national primary law in the sense that nominees be 
Past experience justifies their opinion, but that experience does not prove per se that the problem is insurmountable. Consider the immense audience which viewed the Kennedy-Nixon debates in I960. Mass communications media offer possibilities unavailable when early primary laws were drafted and the opportunities available have been considered rather superficially to date. Broadcasting not only would reduce the expense involved, but it could limit the traveling required by candidates and the length of the campaign. Expenses would be equalized in a very practical way if campaigning were limited to a series of debates and private contributions banned. The South Dakota law was criticized because it required candidates to come to that state to participate in debates. ${ }^{10}$ Remote control pickups would make such a trip unnecessary, yet take advantage of the device to present the candidate's views. Frequent use of these media would prevent our Presidents from approaching physical exhaustion before they enter the White House.

State or federal financing of campaigns has long been under discussion. ${ }^{11}$ But the cry of "socialism," which is not without merit in the case of some proposals, has prevented positive action. Why not let those who wish to participate in the preferential primary pay for the privilege and thus defray the cost to the state and equalize the burden of expenses among the candidates? This could be done through adoption of an idea advanced by Professor J. B. Shannon, of the University of Nebraska. His proposal is based on a study of campaign expenditures in Norway, as well as the United States. Shannon recommends that, ${ }^{12}$

... the voters themselves . . . determine how their money shall be spent. The large number of income taxpayers suggests a method for achieving this end. Let Congress appropriate to political parties, for example, one dollar for each income taxpayer who is willing to signify the party of his choice. This could be done simply on a detachable coupon on each income tax return. There are between forty and fifty million taxpayers. Let us suppose that ten million people authorized a dollar to the Democratic Party and ten million to the Republicans. This would place each party on a permanent basis for operating each year. It could insure organization in each state of a party body seeking to advance the interest of an opposition party as well as the dominant party. . . .

Certainly the national party could appropriate some of its funds to be used in holding debates, discussions and roundtables among its adherents where candidates for nomination

determined that way. It would remove a great deal of the glamour and interest engendered by a convention, and the opportunities for fraud would be tremendous." Letter from Joseph W. Martin, Jr., to the author, Aug. 13, I959.

SAM RAYBURN (Late Speaker of the House and three-time Chairman of the Democratic National Convention"): "The idea of a national nominating primary has always seemed to me an ineffective way to approach the problem of selecting Presidential and Vice Presidential candidates, and I am sure that it would be so expensive as to be impractical." Letter from Sam Rayburn to the author, Aug. 18, I959.

${ }^{10} 30$ National Conference of Commissioners on Uniform State Laws [hereinafter cited NCCUSL] Proceedings 259 (I920).

${ }^{21}$ President Truman recalled that when he was in the Senate, Norris and Hatch discussed federal financing of elections. President Theodore Roosevelt had proposed the idea in Igr2 and President Kennedy endorsed such legislation at a recent press conference in 196r. See Hearings Before the Subcommittee on Privileges and Elections of the Senate Committee on Rules and Administration, on Proposed Amendments to and Improvements in the Federal Election Laws, pt. I, 87th Cong., Ist Sess. (196I).

${ }^{12}$ J. B. Shannon, Money and Politics 93, 95 (I959). 
would have free time to display their personalities and policy suggestions before party followers.

$\ldots$

Of course, this is a bare outline of what could be done. All novel suggestions are open to criticism as to detail of operation. This one is meant to point a possible way over what has been regarded as an insuperable barrier to appropriation of public funds for party purposes. It goes without saying that as a condition of acceptance of such funds the parties would set up the best technical type of financial auditing and accounting of all funds, with financial reports open to all parties, and the press and other media of communication.

\section{III}

\section{A New Approach}

If the federal constitution had allowed a national initiative there is every reason to believe, from samplings of public opinion, that the convention system would have been greatly modified as early as I9I2. In the absence of such a method for enacting a law is there any way for the people to circumvent a hesitant Congress, and reluctant state legislatures, and to establish a national primary?

The United States Supreme Court has affirmed the power of Congress to regulate the election of federal officers. ${ }^{13}$ Nevertheless, election law remains, for the most part, within the jurisdiction of the states, where the initiative does exist. In a recent study of state presidential primary laws a uniform state law was suggested. ${ }^{14}$ This approach offers the only practical solution. ${ }^{15}$

It has become popular to criticize state presidential primaries. Public interest has lagged and the delegates have disregarded the results. The original idea, however, was sound, but legislation failed miserably to implement the basic concept. The purpose of the primary is twofold: (I) to give the people of the state an opportunity to choose between the leading contenders for the presidential nominations-hence the designation presidential "preference" primary; (2) to reflect that preference in the national convention by the voting of the state's delegation. This is simple enough and Americans who have had wide experience in political affairs have agreed with this statement of purpose. ${ }^{16}$

\footnotetext{
${ }^{13}$ Burroughs \& Cannon v. United States, 290 U.S. 534 (I933); United States v. Classic, 3I3 U.S. 299 (1940); Terry v. Allen, 345 U.S. 460 (1953).

14 Hanisen, Performance and Potential of Presidential Primary Laws, 39 NEB. L. Rev. 473 (r960).

15 To the extent they would encourage state action some of the federal bills have possibilities, but their mechanics indicate lack of study or careless draftsmanship. See S. 652, 84th Cong., Ist Sess. (I955). This bill would have the federal government pay the cost of a state primary if the state law met certain minimum requirements. But, (I) there was no requirement that all of the candidates appear on the ballot, (2) the delegates would be bound by a formula which has no basis in experience or logic, (3) expressed personal preferences of the delegates could conflict with their instructions to vote for the winner, (4) there was no uniform date for holding the primary, and (5) there was no suggestion made for meeting the expense problem.

${ }^{10}$ Letter from Bernard M. Baruch to the author, Dec. 20, 1960 ; letter from Eleanor Roosevelt to the author, Nov. 30, 1960; letter from Herbert Hoover to the author, Dec. 2, 1960: "I would agree with the description of the purpose of the State Primaries ... and I have always supported them, usually with some remark about the obnoxious procedure of 'convention' states"; letter from Louise Overacker to the author, Dec. 13, 1960.
} 
The fault with our present primary laws, and the majority of those in effect over the past fifty-odd years, is that they have not given the people a choice among the leading contenders for the nomination. During the period $1912-1956$, nominees for the Presidency were chosen twenty-six times. There were opportunities for 185 primary elections. But, with all of these opportunities, in only twenty-four instances, twelve per cent, were all of the contenders entered in the presidential primaries. ${ }^{17}$

It is absurd to expect public interest under such circumstances, and yet that is what critics of the primary have done. They have condemned the primaries generally, on the basis of poorly drawn laws, and have failed to consider what has happened in the representative twenty-four instances where all aspirants were entered in the primary. In those cases public interest was intense and the voting reflected it. Furthermore, the delegates to the convention supported the primary winner as long as it was practical to do so. ${ }^{18}$ And in eighteen of these twenty-four primaries there were no laws binding the delegates. ${ }^{10}$ Thus, the facts prove that, when the mechanics of the law have implemented the first objective of the primary (placing all the candidates on the ballot), the second (delegate support for the winner) naturally follows.

A uniform law, then, should have as its foremost objective placing the names of all the candidates on the ballot in as simple a manner as possible. ${ }^{20}$ If this is not done, then what is the purpose of the primary? It becomes merely a tool for politicians who will run in the states where they can win and avoid contests where they will lose. The choice under such circumstances is with the candidate, not the people.

If the names of all the candidates are placed on the ballot there is a concomitant duty and responsibility to equalize the burden of expenses for the candidates; otherwise the primary will, indeed, become "a rich man's game." The suggestions offered to solve the problem on the federal level, like Shannon's proposal, could be adapted to the individual states, ${ }^{21}$ and combined with a provision for campaigning through a series of debates broadcast over a state television and radio hook-up. ${ }^{22} \mathrm{~A}$ uniform law implies a uniform date for the primary, and so, if more than one state adopted an identical law, it would not be necessary for candidates to multiply their campaigning. The radio and television network for the debates could simply be expanded to include the stations in other states. Such a uniform law would give the presidential primary its first real opportunity to show its potential.

${ }^{27}$ See Hansen, supra note $x_{4}$, at 475,476 .

${ }^{18}$ Id. at 500 , chart III.

${ }^{10}$ Id. at 502.

${ }^{20}$ The r960 Nebraska Democratic ballot illustrates the length of some ballots. Only Kennedy's name appeared on the preference section, but the voter was required to choose sixteen delegates from a list of fifty candidates for delegate and there was no indication of the preference of the delegates for President.

${ }^{21}$ Shannon's suggestion could be readily applied to the state level. The detachable coupon could be made part of the state property or income tax form. The state would thus be relieved of the impossible task of "policing" private contributions.

${ }^{22}$ Objection is always raised that debating skill should not be the sole qualification for the Presidency. This assumes that viewers or listeners judge on an extremely limited basis. Persuasiveness is not a handicap to any President. Moreover, there need be no requirement that the form of the Kennedy-Nixon debates be followed, since it was subject to justifiable criticism. 
Basically, this is not a new, radical, or revolutionary approach. Those who initiated the primary movement harbored the idea that other states would pattern their laws on those adopted in Nebraska and Oregon, with uniformity as a natural development. The lack of a central organization to give direction to the movement, ignorance, lack of experience, and the very nature of our federal system combined to make this hope illusory. But in spite of the fact that primary laws have been criticized, the idea and the philosophy behind it have taken root.

This is illustrated by the history of the Conference of the Commissioners on Uniform Laws. In Ig20, Nathan William McChesney, distinguished lawyer, politician, and subsequently president of the organization, offered a resolution asking for appointment of a Committee on a Uniform Primary Law. ${ }^{23}$ Although the words "Federal Officers" were used, McChesney made it clear that the resolution was directed at the varying requirements of presidential primary laws. The Conference adopted the resolution, but there was a misunderstanding by the members of the appointed committee as to their function. Delay resulted; and when the committee finally gave its report in I923, it was apparent that the members had discussed the pros and cons of the desirability of presidential primaries and reached an adverse conclusion with reference to them. McChesney, then president of the Conference, noted this fact: $:^{24}$

The fact remains that whether we personally do or do not approve of the system ... there are primary acts in force in numerous states applying to presidential candidates and that uniformity of provisions even as to the mere matter of form of petition and date of election would greatly simplify matters. It is hoped that the committee will be continued with instructions to carry out the mandate of the conference to prepare a uniform act, and I so recommend.

The committee was continued under the chairmanship of Arthur $\mathrm{H}$. Ryall of Michigan, who reported to the I924 meeting that material was being assembled. ${ }^{25}$ In 1925 the proposed $a^{26}{ }^{26}$ was considered by the Conference. By that year the presidential primary was in the "doldrums" of public opinion. The lack of any real contests in I9I6 in either party, the widely variant laws in effect in the I920 campaign, the lack of opposition to Coolidge in $1924,{ }^{27}$ and the serious split in the Democratic Party that year-all of these factors produced disillusionment and indifference among many people who had previously supported the idea enthusiastically. The report of the 1923 committee left no doubt that many of the commissioners flatly opposed the basic idea of the presidential primary. It was against such a background that the uniform law came up for consideration. ${ }^{28}$

23 See 30 NCCUSL Proceedings 259 (I920).

24 33 NCCUSL Procendings 88-89 (x923). For the report of the committee appointed, see id. at 283 ff.

${ }_{25} 34$ NCCUSL Proceedings 285 (1924).

3035 NCCUSL Proceedings 842-43 (I925).

27 Will Rogers remarked that "Coolidge could have been nominated by post card."

${ }^{28} 35$ NCCUSL Proceedings 82-95 (1925). 
Mr. Ryall outlined the law to the Conference. It provided for: $:^{29}$

(I) a uniform date, preferably between March 15 th and May rst;

(2) elimination of the requirement that a candidate must go to the specific state to take part in a debate;

(3) a limit on expenditures;

(4) party enrollment by the voters.

He reiterated his own dislike for the primary: ${ }^{30}$

I have no more love for it than some of the rest of you, but it is here and we feel that if this Conference can bring about two or three things which will eliminate some of the most serious objections to it, we have accomplished a real work....

President McChesney spoke in the same vein, as did A. W. Shands of Mississippi, but there was determined opposition by Joseph C. O'Mahoney of Wyoming (later to become a United States Senator), W. H. Washington of Tennessee, and Charles M. Dutcher of Iowa.

Mr. Washington's chief objection was that there was a growing sentiment in the country against primary elections and any action by the Conference might look like an endorsement of the system, thus impeding its abolition. ${ }^{31}$

Dutcher, of Iowa, shared this view and emphasized that any endorsement of the primary movement would undermine our republican, representative system of government. $^{32}$ O'Mahoney pointed out that it was the duty of the Conference to draft uniform laws and since only sixteen states had primary laws the matter should be dropped.33

Chairman Ryall responded to O'Mahoney's remarks by emphasizing the fact that twenty-five states, well over half, had adopted such laws since 1905 . Not all states, said Ryall, have dairying as their principal agricultural activity, but that did not prevent the Conference from considering a uniform milk act that same day. S. R. Child of Minnesota reminded "those members who are talking about uniformity that we have passed the point where the acts we frame are ones that have a uniformity of interest in all the states."34

The attitude of the Conference was sensed by Max Shoetz of Wisconsin, himself an advocate of the primary, who stated that "I do not want it to be regulated by a body so unfriendly to it." ${ }^{35}$ A motion to lay on the table was put to a vote, and carried twenty-seven to eight. ${ }^{38}$ And so the 1925 Conference, in Mr. Washington's words, decided not to impede the repeal of the presidential primary laws.

Those who were present at that meeting and survived until ig6o must have been surprised and shocked, not only at the survival of the primary, but by the influential part it played in the nomination of President Eisenhower in 1952, Mr. Stevenson in 1956, and President Kennedy in 1960 . The history of primaries since the Commissioners intoned the requiem in 1925 reminds one of Churchill's comment in
"Ibid.
${ }^{90} 1 d$. at 83 .
${ }^{32}$ Id. at 89.
${ }^{3 s}$ Id. at $9 \mathrm{I}$.
${ }^{35}$ Ibid.
${ }^{21} 1 d$. at 88 .
st $l d$. at 94 .
${ }^{80}$ Id. at 95 . 
I94I after the fall of France. The French generals predicted that England would "have its neck wrung like a chicken in six months." Sir Winston replied later: "Some chicken-some neck."

The failure of the 1925 Commissioners to take action has contributed to a perpetuation of the evils which the proposed act sought to correct; further experience has revealed other defects. In spite of these, primary laws have remained in effect; were they corrected, the idea might prove feasible after all.

Perhaps the Conference might reach different conclusions if the matter were reconsidered in the I960's. The proposed act, appended hereto, would correct the abuses which have become apparent. If such a law, identical in its basic provisions, were adopted in several large states, we would, as a practical matter, have a national primary. It would result from state action and emanate from the people themselves, the repository of all governmental power, especially in a representative democracy.

\section{APPENDIX}

\section{PROPOSED UNIFORM PRESIDENTIAL PRIMARY ACT}

Section r. A presidential preference primary shall be held in this state each year in which a President of the United States is to be nominated. The election shall be held on the second Tuesday in May, or forty-five days before the convening of the first major party convention, whichever is closer to the time of the convention.

Section 2. The purpose of this law shall be to give the qualified electors of the state an opportunity to express their preference among all the leading contenders for their party's nomination and to elect delegates to the national conventions of both parties who will reflect the preference so expressed by the electorate.

Section 3. If, in any presidential election year, the Secretary of State shall, in his sole discretion, determine that there is no contest in a party for that party's presidential nomination, no primary shall be held for the party so designated that year.

Section 4. Definitions:

(a) "Elector" as used in this act shall mean any person who has complied with the election laws of this state at the time of the primary; Provided, However, that he was registered more than six months prior to the date of the primary election with the party in whose primary he wishes to vote. Any person changing his party affiliation in the six months period preceding the primary election shall be barred from voting in such election for his preference for president.

(b) "Political party" or "Party" as used in this act shall mean any political party which received more than fifteen per cent of the vote in the last gubernatorial election.

(c) "Candidate for President" as used in this act shall mean any person seeking the nomination of his party for President of the United States, whose name shall be placed on the ballot by his own action, petition of his supporters, or the Secretary of State, as hereinafter provided. 
(d) "Candidate for delegate" as used in this act shall mean any qualified elector who files with the Secretary of State in the manner hereinafter provided and who shall have been registered with the party in whose election he wishes to enter, at least six months prior to the election.

Section 5. In order to fulfill the purposes of this act as expressed in section two, the name of a candidate for President of the United States shall be placed on the ballot for the presidential preference primary if the following conditions are met:

(a) If the candidate does not reside in this state:

(I) He may voluntarily enter the primary by making a declaration of his candidacy, filing with the Secretary of State, either by mail or in person, and paying a one hundred dollar fee. He must also present an affidavit from the Chairman of the National Committee of his party stating that he is a member in good standing.

(2) His supporters in this state may enter his name by filing with the Secretary of State a petition, signed by at least fifty qualified electors from each congressional district in the state, requesting that his name be placed on the ballot, and paying the one hundred dollar filing fee.

(3) The Secretary of State shall determine, in his sole discretion, that such candidate's candidacy is generally advocated or recognized in national news media throughout the United States.

(b) If the candidate resides within the state:

(I) By petition of five hundred of his supporters from each congressional district in the state, and payment of the filing fee, or

(2) if the Secretary of State, in his sole discretion, shall determine that such candidate's candidacy is generally advocated or recognized throughout the United States.

No candidate entered in the presidential preference primary may withdraw his name from consideration by the voters unless he expressly states in a letter to the Secretary of State that he is not a candidate and will not accept his party's nomination or serve if elected. The Secretary of State is instructed to withdraw a candidate's name only if such candidate has sent such a letter to the Secretary of State, or in the event of such candidate's death or permanent disability. All filings must be completed 30 days before the date of the primary.

Section 6. Expenditures of money or other emoluments on behalf of any candidate for the nomination for President shall be unlawful. Campaigning shall be limited to a series of four debates between the candidates so entered; such debates to be broadcast by all television and radio stations within the state, one debate to be held on each of four consecutive Monday evenings immediately prior to the date of the presidential preference primary. The last debate shall be held on the evening before the election. For the purposes of such debates no candidate for President so entered in the primary shall be required to be personally within the state, provided arrangements can be made for his participation by remote broadcasting pick-up, any 
expense incident to arranging the broadcast to be paid out of the state general fund.

Section 7. Candidates for delegate to the national convention of their party shall file with the Secretary of State not less than 30 days prior to the election. Such candidates shall state their preference among the candidates of their party for President of the United States, or that they wish to run as an "uninstructed" delegate. The number of delegates to be elected to the convention shall be in accord with the call as issued by that party's national committee, provided that two delegates shall be elected from each congressional district, and the balance at large.

The Secretary of State shall consider the first complete set of candidates for delegates, who file individually or jointly, as bona fide candidates preferring the presidential candidate designated, unless such presidential candidate shall disavow their support and submit his own list of qualified delegates. The same conditions shall apply to "uninstructed" delegates, except that if a full ticket shall not file with the Secretary of State, that party's central committee shall submit the balance of names required within 48 hours of notification.

The names of candidates for delegate shall not be listed on the ballot. Election of delegates shall be determined on the basis of the vote cast for the presidential candidates or an uninstructed delegation, in each congressional district and in the state at large.

Section 8. Immediately after election each delegate shall certify to the Secretary of State his choice as alternate delegate, together with a statement by the person so designated accepting the position.

Section 9. The Secretary of State shall provide a space on the ballot for voters who wish to write-in the name of a candidate not entered, and such write-in votes shall be counted for such candidates as long as the name of the candidate can be ascertained by a reasonable person and regardless of misspelling or failure to write an " $X$ " in the box immediately before the space.

The Secretary of State shall similarly provide a place for listing the words "Uninstructed Delegation" for voters who do not wish to cast their vote for any of the candidates entered in the primary or write in the name of a candidate.

Section ro. Delegates elected shall be morally bound to support the candidate for whom they have expressed a preference and for so long a time as they, in their sole judgment, shall deem practical, remembering at all times that they are elected under a representative form of government and should have as their major concern the welfare of the nation and this state.

Section II. Sections I-II inclusive shall be cited as the Uniform Presidential Primary Act. 